\title{
Comparative prognostics in forming and expertise of teacher education environment
}

\author{
Irina I. Sokolova ${ }^{1, *}$, and Aleksandra Yu. Sergienko ${ }^{2}$ \\ ${ }^{1}$ IME RAE, director, St.Petersburg, Russia \\ ${ }^{2}$ IME RAE, laboratory of methodology and prognostics of teacher education development, St.Petersburg, Russia
}

\begin{abstract}
The article discusses social and economic institutional, conceptual, organizational, and technological system aspects of conceptual foresight of teacher education environment by means of comparative studies. The authors present the system solutions for building continuing pedagogical training, recourses for expertize and prognostics of education environment development, most successful and promising for Russia.
\end{abstract}

There are global processes and problems, crises of usual personal identities related to dynamic changes in social and cultural situation in knowledge society. These challenges bring a question of theoretical and empirical ways of creation of integrated education environment to the forefront of scientific (methodological) reflection.

Thus questions arise about the high quality content of education in this integrated education environment connected with an integrated market of products, services and capital. Herewith the issue of teaching and learning standards arises where education is viewed as a creation of some universal person. However, organization of educational institutions, content of learning processes and results of educational activity depend largely on nationality, belief system and specific features of a particular country. Comparative studies in this case allow properly reflect peculiarities of education policy, theory and practice of some countries against others. These studies also allow making scenarios and prognoses, viewing the results of reforms and analyzing effective solutions and risks.

Comparative studies in education, comparative pedagogics show that although there is a unique set of values, ideas, content components and teaching methods in every country, strong entireties exist being out of local specifics. In this case comparative studies in education help us determine universals in education, organizational and educational structures and systems allowing improvement of education quality.

A large body of research shows that comparative pedagogics encourages the raise of education standards and teacher education quality. It gives knowledge about some foreign innovations in education, raises the question why some of them become accepted in the education system of our country and others do not. As a rule, there are three components usually in comparative study: context (socio-cultural conditions, education policy, pedagogical theories and schools of one or another country), content of subject matter, and betweencountries comparison. Comparativism also makes education system ready for necessary specific innovations. In this field comparative studies face methodological problems starting from terms and perceptions. For a foreign (for example, Russian) reader the meaning of terms is controversial since it has different meaning in the national pedagogics. Comparative pedagogics identifies, investigates, explains similar and different in education - terms, discourse, and practices by means of defined comparable units.

In the context of our studies it is suitable to consider prognostic scenarios of system construction of pedagogical education as a modelling of corresponding education environment within the framework of comparative prognostics. We will consider the education environment as an objective world, combination of objects related to education, away of their existence where the actor of education process acts as a perceiving person who influences the environment, explores it, and builds their own existence in it. Our definition is close to the interpretation given by S.V. Ivanova [1].

Comparative prognostics can use expert evaluation methods including foresight, allowing determining longterm perspectives of development, revealing technological innovations in education area along with tactical and strategic advantages of some competing ideas to get the best effect. Other methods to use in prognostic studies are analog method, method of organized strategies, phenomenological, synergetic and hermeneutic methods. In humanitarian studies one can also use heuristic methods - Delphi, factory method, template method, empathy, heuristics questions et al [2].

Prognostics of teacher education development in all countries are a vital task today. To develop scenarios of tomorrow education one needs theoretical and practical research including looking at effective systems, personalization of progressive schools, and projecting

Corresponding author: ipo@iporao.ru 
approximate scenarios of teacher education development based on international comparisons.

At first sight institutional aspects of teacher education environment look particularly important. In Russia reorganization of institutions was given the priority to in the process of modernization reforms. However, there are no research results assuring the preference of parallel (theory and practice at the same time) to sequential (theory first, then practice) model of teacher training, or fundamental to practice-oriented model, or extensive to intensive model. No one can say with confidence which institutional environment is better to train teachers - classic university or pedagogical university. There are examples of highly skilled graduates from both types of universities who later became outstanding gifted educators. Thus V.A. Sidorkin [3] emphasizes that many great specialists in education in the USA graduate from local universities (University of Michigan at Ann Arbor, San Jose State University, St. Cloud State University, Emporia State University, Northwestern State University Natchitoches, California State University, University of North Carolina, Northern Arizona University, Montclair State University et al.). However, he notices a global world tendency of pedagogical universities' transfer to classic universities. One should analyze the best practices of this transfer process. Our research shows that one of the most important roles for mass teacher education is played by the special humanitarian environment of pedagogical university. Another important trend is a need for variative programs of teacher training.

Rather serious issue of teacher education development prognostics remains a requirement for professional pedagogical education for successive teaching practice. Literature sources agree on this issue [4].

In all countries of OECD (Organization for Economic Cooperation and Development) to become a teacher one should get higher education degree (bachelor, master or higher) that takes from 3 (in Belgium) to 6.5 years (Germany and Luxemburg) of study [5].

The model of teacher training organization depends on national traditions in pedagogical theory and practice and financial support of education system. For example, the clinical training model based on collaboration of universities and schools and intensive practices including one year internship has been popular in the USA for over 50 years [3], although the effectiveness of this model is not decisive. More recently another model becomes popular in Russia - the Added Value Model [3]. It suggests evaluating teacher training institutions by evaluating achievements of students taught by their graduates. This model's effectiveness is still a hypothesis since there was no valid research done to prove it.

Informatization of education makes vital changes in teacher education environment. The world accessible banks of lectures, learner and teacher manuals are forming, as well as collections of best teaching practices presentations [3]. Teacher education becomes more open, teachers' communities and corporate education more powerful.
To make prognoses of education environment of modern teacher training it is appropriate to use a deficiency approach. The comparison of foreign and native documents stating the demands to the basic skills for the $21^{\text {st }}$ century allowed [6] determining the deficiency components of teacher training needed to work in the global information education environment:

- ability to work with large body of information (system "person - knowledge pool"): skills of formulating search requests ("googling"), skills of making mental maps (mindmapping), skills of recognizing patterns;

- communicative skills: structured 'ecological' communication; skills of using nonverbal communication; appearing of proto artificial intelligence - development of interfaces 'man - computer';

- creativity: controlled individual creativity mastering creative groups methods;

- ability for re-skilling: development of "learning to learn" skills; lifelong learning approach instead of "completed education".

Our research in Russia (selection of 321 respondents from 20 regions) [7] showed that young teachers mostly lack practical skills of communication with kids and experience of behavior in irregular situations. They have difficulties in making effective lessons (57\%), motivating students in subject $(53 \%)$, and cooperation with parents $(52 \%)$. These deficiencies in teachers' training might become orienting points for constructing the content of teacher education.

Comparative studies show that countries actively developing new effective educational systems usually have higher quality of life. It was revealed that the best solutions were always system solutions. The highest results education systems demonstrate when teacher is in the center - quality of teacher education and teaching, professional development and teacher status value. Considering possible system transfer of best practices of teacher training, professional growth and motivation, one should look at the experience of Finland and Singapore.

According to estimates of PISA (Programme for International Student Assessment) and OECD (Organization for Economic Cooperation and Development), Finland is a leader in school education quality. Teacher profession is one of the most respectful and desired in Finland. At the same time, there is a strong system of selection for those wishing to become a teacher - only about $12 \%$ of best university graduates become teachers [8]. All preschool and elementary school teachers in Finland must have a master's degree.

Key elements of the system of high-quality teacher training in Singapore are [9]:

Recruitment from the top one third of the secondary school graduating class. Interest in teaching is seeded early through teaching internships and a system for midcareer entry also exists.

Training. All teachers train on the Singapore curriculum for at least three years receiving a stipend equivalent to $60 \%$ of a teacher salary. There is a close working relationship between the Institute and schools, where master teachers mentor every new teacher for several years. 
Professional Development. Teachers are entitled to 100 hours of professional development per year. Each school has a fund through which it can support teacher growth, including the development of fresh perspectives by going abroad to examine aspects of education in other countries. A Singapore Teachers' Centre was open at the end of 2010 to further encourage teachers to continuously share best practices. Every teacher is responsible for own professional development. More is teacher's responsibility, more is teacher's autonomy. The same works for Finnish teachers.

Career Development. Talent is identified and nurtured rather than being left to chance. After three years of teaching, teachers are assessed annually to see whether they have the potential for three different career paths - master teacher, specialist in curriculum or research, or school leader, each with salary increments.

System comparative analysis and reflection on alternatives allow concluding that there are necessary factors on the way to successful confident teacher: variability of teacher professional development routs, professional growth resources availability, evident criteria of professional development stages, attention to teacher' personality. Such a teacher is a guarantee of education system success. Our research [7] showed that young teachers value their profession for the chance to work with children $(81 \%)$, creative self-actualization $(58 \%)$, sense of doing something meaningful $(56 \%)$. This points to the fact that young teachers are motivated by teaching profession as creative, humanitarian profession, and feel responsible for the results of their teaching.

Besides pedagogical education in some countries (Sweden, Great Britain, Slovenia, Brazil, Israel, Greece) it is necessary to get a teaching license to teach. A probation period for a beginning teacher is also popular; it lasts from 4.8 months (Ireland) to 3 years (Brazil). In 25 from 34 (investigated) countries a person with pedagogical education may teach right after the graduation. Generally there is a probation period for young teachers in 14 countries [5]. Is it of high priority for Russia? At least not of first priority, though these issues become raised in some researches and documents related to teacher education.

Large part of OECD countries [5] has programs of young teachers' individualized support including financial support (8 countries), reduced work load (3 countries) or other forms of support (3 countries). In Russia such a support depends on a region, but it has always been a great help for beginning teacher, especially for rural teachers. It is still an important social and motivation factor now. In the majority of investigated countries there are special introduction programs to the profession; moreover in most of them these programs are obligatory. In our country this problem is being solved by young teacher support programs and mentoring. However, this is not enough, and this issue remains topical for teacher education prognostics.

Nevertheless many teachers leave the profession within first 5 years of work at school. In the INES (Education Indicators Project) research [5] (though only
6 countries submitted such data) it was shown that from $22 \%$ (Belgium) to $30 \%$ (Norway) have left the profession. Our research proves these results [7]. 76\% of teachers with a working period of 1 year and less plan to stay in the profession. But only $50 \%$ of teachers with a working period of 2 years plan to stay, others wish to leave school or change the profession.

The problem of career development is particularly acute for teachers and needs to be solved. The attractiveness of teaching profession is higher when both vertical and horizontal career lines are supported, wide set of categories is available, and the criteria for differentiation of demands and salaries are strictly defined.

It was shown in many studies that salary level influences the choice and reputation of teaching profession. The salary level is to wide extent defined by the level of country' economic development, while it must be emphasized that there is no direct relationship between teacher salary level and students' achievements found in international studies [5].

L. Darling-Hammond's research [10] analyzed countries successful in teacher training and revealed some contributing factors: system approach, careful selection and active training of students, attractive terms of teacher's labor, professional retraining, and leadership development. The idea of necessary system social, pedagogical and organizational changes in teacher education was also promoted in the report by A. Schleicher in 2011 [11]. This OECD Teaching and Learning International Survey showed that some isolated reforms do not make a change:

- raising of admission score for prospective pedagogical university students will result in teachers deficiency without a support of good working conditions and high salary;

- raising of salaries and better working conditions will not automatically lead to improvement of teaching quality without tightening the admission tests;

- effect of teachers' evaluation system will be limited, if the evaluation results are only important for salary accounting, but not for professional or career development;

- providing teachers autonomy might be counterproductive if their education and training is far from perfect.

Best systems of education have clear criteria for teachers' knowledge and skills in subject areas, and well-defined meaning of qualified teaching. Our understanding is that these conclusions are very important. In terms of prognostics there are some important tasks to work on: teacher qualifications design, professional standards, renovation of certification requirements and teacher education standards. Apparently prognostics requirements matrix might become the base for expertizing successful teacher training systems.

Ensuring comfortable labor conditions for teacher, raising of special requirements for teacher candidates, enhancing career development, social support, culture bonuses (for example, voucher to a museum), and at last, movement to great responsibility and autonomy of 
teacher and school - is a challenging prognosis for development of education environment providing productive teacher work in Russia based on comparative studies.

\section{References}

1. S.V. Ivanova, Tsennosti i Smysly 6, 23-28 (2015) [In Rus]

2. V.I. Andreev, Kontseptualnaia pedagogicheskaia prognostika (Center for Innovation Technologies, Kazan, 2010) [In Rus]

3. A.M. Sidorkin, Educational Studies, 1, 136-155 (2013) [In Rus]

4. K.A. Gansle, G.H. Noell, J.M. Burns, J. of Teacher Ed., 63, 5, 304-317 (2013)

5. M.L. Agranovich, O.V. Zaitseva, U.V. Ermachkova, Rossiiskoe obrazovanie v kontekste mezhdunarodnih indikatorov. Shkolniy uchitel: obrazovanie, nagruzka, zarplata, Available online: URL http://www.mamso.ru/node/73540 (accessed on: 13.01.2016) [In Rus]
6. I.I. Sokolova, L.S. Ilyushin, O.N. Shilova, Chelovek i obrazovanie, 3(44), 45-52 (2015) [In Rus]

7. A.Yu. Sergienko, Chelovek i obrazovanie, 2(39), 130-137 (2014) [In Rus]

8. Kak gotovyat uchiteley $v$ Finliandii, available online:

URL

http://www.akvobr.ru/kak gotovjat uchitelei v fin ljandii.html (accessed on: 30.11.2015) [In Rus]

9. A.Yu. Sergienko, L.G. Panfilova, I.I. Sokolova, Chelovek i obrazovanie, 3(44), 151-159 (2015)

10. L. Darling-Hammond, and R. Rothman (Eds.) Teacher and Leader Effectiveness in HighPerforming Education Systems (Stanford Center for Opportunity Policy in Education, Stanford, 2011).

11. A. Schleicher, Educational Studies, 2, 5-62 (2012) 